\title{
Seven Decades of Trans-Atlantic Cooperation in the Development of EPMA
}

\author{
John Fournelle ${ }^{1}$
}

1. Cameron EPMA Laboratory, Department of Geoscience, University of Wisconsin, Madison, WI, USA

The year 2017 marks the $50^{\text {th }}$ anniversary of the founding of the Microanalysis Society (formerly the Microbeam Analysis Society, originally the Electron Probe Analysis Society of America). The 1967 founding culminated several years of meetings of both local/regional groups and several national meetings where the practioners of the new field of electron probe microanalysis met to discuss a range of practical — and theoretical-topics they were encountering in their work. A few individuals attended periodic international meetings. What is poorly documented, however, is that two decades prior to 1967, a series of trans-Atlantic visits by scientists led to information and technology exchanges that directly resulted in EPMA's rapid development and acceptance as a critical tool in science and technology. With the end of World War 2, scientific exchanges blossomed. In January 1947, André Guinier and Raimond Castaing joined ONERA, and immediately Guinier set off for a 2 month tour of several material science research facilities in the U.S., encouraged by a similar visit by metallurgist Charles Crussard a year or so previously (Guinier and Crussard's twin brother were schoolmates--it's a small world [1]). Crussard and Guinier felt that science and technology in France needed a post-war revitalization [2], and hoped to learn something from the American experience. Guinier would write an article entitled "L'esprit de la recherché aux U.S.A.” in the magazine Atomes (Tous les Aspects Scientiques d'un nouvel age)[3].

It is not commonly known, but Castaing and Guinier made several trips to the U.S. in the early 1950s. These occasions provided for important "technology transfer" to American scientists. It turns out that both Guinier and one of the early American probers (and founders of EPASA), Verne Birks, attended the 8th Pittsburgh Conference on X-ray and Electron Diffraction in November 1950 and were in the same X-ray session. Guinier spoke on refinements in the design of rotating anode X-ray tubes and Birks spoke on developments in XRF -- use of vacuum plus wider $2 \mathrm{~d}$ crystals "to extend the range of analysis from $\mathrm{Ca}$ down to the next row of lighter elements". One may guess that Birks may have learned here, perhaps over beer or cocktails, about the work Guinier's student Castaing was finishing at that moment. Then in late October and early November of 1951, Castaing himself came to the U.S. and introduced the electron probe for the first time to the American scientific audience. As he relates in his historical article in "The Green Book" [4], he gave a short talk, squeezed in at the last minute, to the American Physical Society's October meeting in Chicago; a few days later, he spoke at the Symposium on Electron Physics held at the National Bureau of Standards in Washington, DC upon the occasion of its 50th anniversary [5,6]. Interestingly, a week later, the 9th annual meeting of EMSA was held in Philadelphia, but Castaing was not listed in the program and presumably was not present. Thereafter, Guinier and Castaing made a point of highlighting applications of this new instrument. In September, 1952, the American Chemical Society organized a Symposium on X-rays as an Analytical Chemical Tool at Atlantic City, NJ. Castaing and Guinier presented "Point-by-Point Analysis by X-ray Spectroscopy" [7], while Birks spoke on XRF. At the March 1953 Pittsburgh Conference on Analytical Chemistry and Applied Spectroscopy, the record indicates a talk by Guinier and Castaing "Point by Point Chemical Analysis by X-ray Spectrography" and it appears that Guinier may have been on sabbatical at the University of Illinois, Urbana. Castaing mentioned that Birks visited him at his lab and brought a sample to analyze with the probe; Birks said it was a "tungsten alloy" but Castaing found it was totally different and said he suspected this was a test to see exactly how good this new instrument was [4]. Records 
found in the files of David Wittry suggest that the next time Castaing visited the US was in February 1958, when Verne Birks organized, with Office of Naval Research support, a Conference on Electron Probe Microanalyzers in Washington, DC, at the National Academy of Sciences. Castaing was the keynote speaker, and among the 46 invited participants were Peter Duncumb and David Wittry, who had each built their own electron beam sourced X-ray detection instruments for their Ph.D. projects, starting in 1953. In 1952, on a train in France, Guinier had met Pol Duwez, a metallurgist and WW2 Belgium refuge who had ended up at Caltech working on ordnance-related metals [8]. Guinier related Castaing's new instrument which had great importance for metals research. Duwez was a research scientist associated with Caltech physics professor Jesse Dumond, who had recently taken on David Wittry as a graduate student. Dumond wanted Wittry to build a field emission probe, and Wittry did try, but only was successful when he switched to a tungsten source. Wittry's design would become the prototype for the successful ARL line of electron probes. Thus, by the mid-1950s, the die had been cast for the transAtlantic spread of technology and ideas for advances in instrumentation for microanalysis. This would be solidified by series of conferences on both sides of the Atlantic with participants coming from afar, such as to the triennial ICXOMs (e.g., Cambridge 1956, Stockholm 1959, Stanford 1962), and yearly Denver X-ray Conferences. The founding of North America's EPASA (MAS) would be a direct result of meetings in 1964 and 1966 in the Washington, DC area of this first generation of electron probe practioners.

\section{References:}

[1] Friedel J, personal communication (2011).

[2] Guinier A in The Origins of Solid-State State Physics in Italy, 1945-1960 (G Giuliana, ed) p. 249.

[3] Guinier A, Atomes 20 (1947), p. 378.

[4] Castaing R in Electron Probe Quantitation (KFJ Heinrich and DE Newbury, eds) p. 1.

[5] Castaing R in Electron Physics (NBS Circular 527) p. 305.

[6] Castaing R in Electron Physics (NBS Circular 527) p. 309.

[7] Castaing R and Guinier A, Analytical Chemistry 25 (1953), p. 724.

[8] Oral history video interview with David Wittry by Sterling Newbury, 1990 (available from MSA)

In memory of Jacques Friedel 1921-2014 